材齢 6 ケ月までの改良土の力学特性に及ぼす物理，化学的性質の影響十 宮下千花* 大田孝* Sanjeewani Dayani** 山崎秀策*** 根岸敦規****

\title{
Effect of Physical and Chemical Characteristics on Mechanical Property of Improved Soils until 6 Months
}

by

\begin{abstract}
Yukika Miyashita*, Takashi OtA*, Dayani SAnjeEwani**, Shusaku Yamazaki*** and Atsunori Negishi****
In this study, the effect of physical and chemical properties on the long term mechanical property of surplus soils improved by lime and cement was investigated by conducting unconfined compression and needle penetration tests on the specimens cured under different conditions. The conditions of curing were set as sealed with plastic wrapping and soaked under pure and acidic water, respectively. As the result of the experiments after about 6 months (168 days) from specimen preparation, effect of soaking on the strengths appeared obviously in the cement treated soil. The unconfined compressive strengths of the soaked specimens were found to be the smallest, while those of the sealed specimens were the largest. It was suggested by the needle penetration resistance that local deterioration progressed gradually from the surface of the soaked specimens. It was inferred that these differences in the strengths between sealed and soaked curing were caused by the changes in physical properties such as degree of saturation, and chemical properties due possibly to the leaching of hydration products during soaked curing.
\end{abstract}

\section{Key words:}

Long term mechanical property, Improved soil, Quick lime, Cement-based product, Unconfined compression test, Needle penetration test, Degree of saturation, Leaching of Ca and $\mathrm{SO}_{4}$

\section{1 はじめに}

建設リサイクルの推進を背景に建設発生土の更なる有 効利用が求められている. 安定処理等で改良, 利用して きた第 4 種発生土や泥土に分類されるような低品質な発 生土も今後更に積極的に利用する必要がある。このよう な改良土が道路盛土に用いられる場合，道路盛土の長期 的な耐久性や安定性は改良土の長期的な力学特性の変化 の影響を受ける。道路盛土に用いられる改良土は深層混 合改良等と比較すると石灰，セメント等の混合率が低く， 供用期間中に雨水や地下水などの水の浸透作用を受けや すいものと考えられる。混合率の高い改良土の長期的な 力学特性への周辺（暴露）環境の影響ついては，特に海 水環境下での挙動などを中心に検討が進められている ${ }^{1), ~}$ 2)が，水の浸透作用を受ける混合率の低い改良土の長期的 な力学特性についてはあまり検討されていない.

本研究では, コーン指数が $400 \mathrm{kN} / \mathrm{m}^{2}$ に満たない低品質 な発生土を固化改良して築造した盛土の，長期的な耐久 性や安定性について基礎的な検討を行うことを目的とし た長期暴露実験を行っている。低品質な砂質土からなる 石灰，セメント改良土の供試体をそれぞれ 3 種類の混合
率で作製し，封縅，水浸の条件で養生しながら，材齢 7 , 28，168 日で力学試験に供した. 本論文では, 封緘, 水浸 養生した改良土供試体の物理, 化学的性質の変化と, こ れらの変化が一軸圧縮強さ, 針貫入抵抗, および針貫入 試験により評価した劣化深度の経時変化などに与える影 響について, 材齢約 6 ケ月（168 日）までの結果に基づい て報告する．

\section{2 実験方法}

$2 \cdot 1$ 実験に用いた地盤材料と改良土供試体の作製方法 実験には茨城県で採取した低品質な砂質土（美浦砂） を用いた. 美浦砂の基本物性と粒度分布を Table 1, Fig. 1 にそれぞれ示す。現地採取した美浦砂に加水して泥状と し, $4.75 \mathrm{~mm}$ ふるいを通過させた後, 自然乾燥させて求 めた物性值である。美浦砂の改良には生石灰（以下，石 灰という）とセメント系固化材（以下，セメントという）

の 2 種類を用いた. 基準ケースの石灰, セメントの混合 率（試料の乾燥質量に対する石灰, セメントの質量比） は, 材齢 7 日の一軸圧縮強さ (以下, $q_{\mathrm{u}}$ という) が $100 \mathrm{kN} / \mathrm{m}^{2}$ 程度となるように設定した。基準ケースの混合率は石灰 で $2.5 \%$ ， セメントで $3.5 \%$ となった。 長期強度特性への

$\dagger$ 原稿受理 令和元年 6月10日 Received June 10, 2019 @2020 The Society of Materials Science, Japan

* 国立研究開発法人土木研究所つくば中央研究所 ₹ $305-8516$ つぐ市南原

Public Works Research Institute, Minamihara, Tsukuba 305-8516.

** 東京大学生産技術研究所 ₹153-8505 目黒区駒場

Institute of Industrial Science, the University of Tokyo, Meguro-ku, Tokyo 153-8505.

*** 国立研究開発法人土木研究所寒地土木研究所 $\bar{T} 062-8602$ 札幌市豊平区平岸

Civil Engineering Research Institute for Cold Region, Toyohira-ku, Sapporo 062-8602.

**** (株)安藤・間 技術研究所 $\overline{7} 305-0822$ つくば市苅間

Hazama Ando Corporation, Karima, Tsukuba 305-0822. 
混合率の影響を調べるため，基準より混合率の高いケー ス（石灰で $3.8 \%$ ， セメントで $5.3 \%$ ）と低いケース（石 灰で $1.2 \%$ ，セメントで $1.7 \%$ ）をそれぞれ設けた.

美浦砂の含水比を $31 \%$ に調整し, 石灰またはセメント をミキサーにより混合した。1 分間混合する毎にボウル 内側面に付着した試料をこそぎ落とし，色ムラがなくな るまで計 5 分間混合した。直径 $50 \mathrm{~mm}$ ，高さ $100 \mathrm{~mm}$ の 円柱供試体を, 地盤工学会基準「安定処理土の静的締固 めによる供試体作製方法（JGS0812-2009）」に準拠して作 製した。供試体の乾燥密度は実施工機械を用いて実施し

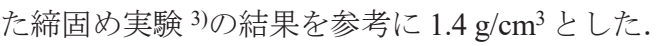

\section{$2 \cdot 2$ 改良土供試体の養生方法}

作製した供試体は，Fig. 2 の下部に示すような封縅と水

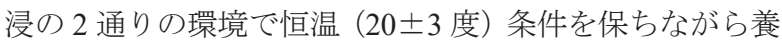
生した. これは例えば Fig. 2 の上部に示すような供用期間 中の道路盛土内の条件を簡易に模擬したものであり，封 緘養生は外的作用の影響を受けにくい部分 (1)，水浸養 生は水の浸透の影響を受ける部分（2)）をそれぞれ想定 している，水浸養生では，硫酸，硝酸，塩酸を 5: $2: 3$ の 割合で混合し，純水を加えて $\mathrm{pH}$ を 4.5 に調整して作製し た模擬酸性雨と, 純水の 2 種類の養生水を用いた。 1 供試 体当たりの養生水量を 1 リットルとし，材齢 4 日から水 浸養生を開始した。材齢 28 日までは 7 日，168 日までは 14 日，それ以降は28日ごとに養生水を交換した。

\section{$2 \cdot 3$ 力学試験方法}

封緘，水浸養生した供試体は，材齢 7，28，168 日で一 軸圧縮試験（JIS A 1216）と針貫入試験（JGS3431）にそ れぞれ供した。ただし，試験装置の制約と荷重変位デー タ計測の精度を考慮して, 針の貫入速度は $11 \mathrm{~mm} / \mathrm{min}$. と した. Fig. 3 に示寸模式図の通り供試体を横向きに寝かせ て設置し, 中央高さにおいて 3 方向から針を貫入させた. 封縅養生の供試体は，不飽和条件と試験の前日に飽和さ せた条件の 2 通りの条件で試験を実施し，飽和度が改良 土の強度に及ぼす影響を調べた。

\section{$2 \cdot 4$ 養生水と改良土の化学分析方法}

交換時に排出した養生水を回収し, $\mathrm{pH}, \mathrm{Ca}$ 濃度, $\mathrm{SO}_{4}$ 濃 度を測定した. $\mathrm{pH}, \mathrm{Ca}$ 濃度の測定にはコンパクトメータ (堀場 LAQUAtwin B-712, B-751)， $\mathrm{SO}_{4}$ 濃度はイオンク ロマトグラフ (JIS K 0102 41.3) によりそれぞれ測定した.

エネルギー分散型蛍光 $\mathrm{X}$ 線分析（以下，XRF という） および湿式分析（JIS R 5202）により得られた美浦砂，生 石灰，セメント系固化材の化学組成を Table 2 に示す.

針貫入試験を行った供試体を乾燥させて樹脂を浸透さ せ, 中央高さ付近の横断面が観察できる試料に切断, 研
磨した。試料調整の簡素化のため，切断と研磨には水を 用いた. 炭素を蒸着させた横断面観察試料に対して EPMA 分析を行い，供試体横断面での主要元素の分布状況を確 認した。

Table 1 Physical and mechanical properties of Miho sand.

\begin{tabular}{|l|c|}
\hline Soil type & Sand with fines \\
\hline Specific gravity, $\rho_{\mathrm{s}}$ & 2.693 \\
\hline Plasticity index, $\mathrm{I}_{\mathrm{P}}$ & 25.4 \\
\hline Optimum water content, $\mathrm{w}_{\text {opt }}(\%)$ & 21.6 \\
\hline Maximum dry density, $\rho_{\text {dmax }}\left(\mathrm{g} / \mathrm{cm}^{3}\right)$ & 1.624 \\
\hline $\begin{array}{l}\text { Cone index, } \mathrm{q}_{\mathrm{c}}\left(\mathrm{kN} / \mathrm{m}^{2}\right) \\
\text { (with water content of } 31 \%)\end{array}$ & 68 \\
\hline
\end{tabular}

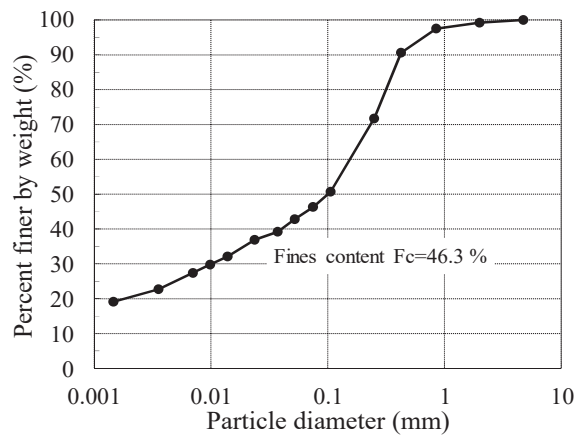

Fig. 1 Grain size distribution of Miho sand.
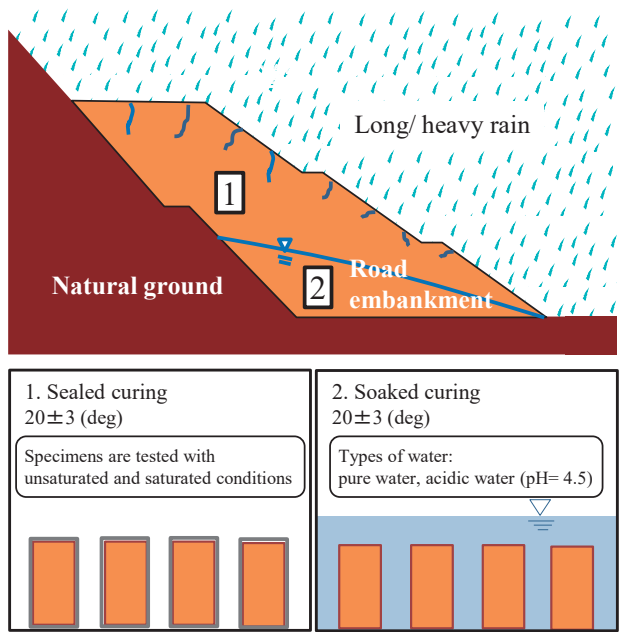

Fig. 2 Schematic figures of environmental exposure conditions in road embankment and curing conditions in laboratory.

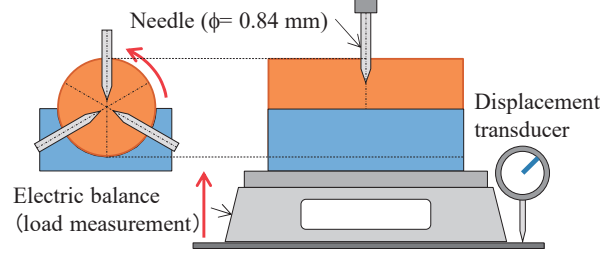

Fig. 3 Test condition of needle penetration.

Table 2 Chemical component of Miho sand, quick lime and cement.

\begin{tabular}{|c|c|c|c|c|c|c|c|c|c|c|c|c|}
\hline & $\begin{array}{c}\mathrm{SiO}_{2} \\
(\mathrm{wt} \%)\end{array}$ & $\begin{array}{c}\mathrm{TiO}_{2} \\
(\mathrm{wt} \%)\end{array}$ & $\begin{array}{c}\mathrm{Al}_{2} \mathrm{O}_{3} \\
(\mathrm{wt} \%)\end{array}$ & $\begin{array}{c}\mathrm{Fe}_{2} \mathrm{O}_{3} \\
(\mathrm{wt} \%)\end{array}$ & $\begin{array}{c}\mathrm{MnO}_{2} \\
(\mathrm{wt} \%)\end{array}$ & $\begin{array}{c}\mathrm{MgO} \\
(\mathrm{wt} \%)\end{array}$ & $\begin{array}{c}\mathrm{CaO} \\
(\mathrm{wt} \%)\end{array}$ & $\begin{array}{c}\mathrm{Na}_{2} \mathrm{O} \\
(\mathrm{wt} \%)\end{array}$ & $\begin{array}{c}\mathrm{K}_{2} \mathrm{O} \\
(\mathrm{wt} \%)\end{array}$ & $\begin{array}{c}\mathrm{P}_{2} \mathrm{O}_{5} \\
(\mathrm{wt} \%)\end{array}$ & $\begin{array}{c}\mathrm{S}_{\text {total }} \\
(\mathrm{wt} \%)\end{array}$ & $\begin{array}{c}\mathrm{SO}_{3} \\
(\mathrm{wt} \%)\end{array}$ \\
\hline Miho sand & 61.7 & 0.73 & 19.9 & 6.86 & 0.11 & 1.29 & 1.48 & 1.18 & 1.54 & 0.10 & 0.03 & - \\
\hline Quick lime & \multicolumn{3}{c|}{ not measured } & 94.9 & not measured & $<0.02$ & - \\
\hline Cement & \multicolumn{3}{c|}{ not measured } & 56.4 & \multicolumn{3}{c|}{ not measured } & 3.13 & 6.08 \\
\hline
\end{tabular}




\section{3 一軸圧縮試験結果}

\section{$3 \cdot 1$ 改良土の一軸圧縮強さに及ぼす物理的性質の影響}

封縅，水浸養生した石灰，セメント改良土の $\mathrm{qu}_{\mathrm{u}}$ 值と材 齢との関係を Figs. 4，5 にそれぞれ示す．L1.2，C1.7\%の 結果はそれぞれ Fig. 4 b)，Fig. 5 b) に別表記した。 L3.8， C5.3 および C $3.5 \%$ の各養生条件と L2.5\%の封縅（不飽 和）養生において，日数の経過に伴う強度増加が確認さ れた. L1.2, C1.7\%の各養生条件と L2.5\%の封縅 (飽和)， 水浸養生では 168 日までの $\mathrm{qu}_{\mathrm{u}}$ 值が 7 日の值からほとんど 変化しなかった. 168 日までは, 水浸養生の qu值に純水, 模擬酸性雨の違いの影響は表れなかった。材齢ごとに比 較すると，いずれの混合条件においても封縅（不飽和） 養生で最も高い qu 值が得られた。石灰改良土は材齢 168 日まで封縅（飽和）と水浸養生の qu 值が概水同程度であ った，セメント改良土は C $1.7 \%$ で 7 日，C $3.5 \%$ で 28 日か ら水浸養生の qu 值が封緘（飽和）養生の $\mathrm{qu}_{\mathrm{u}}$ 值を下回り, C5.3\%も 168 日では水浸養生の $\mathrm{qu}$ 值が最も小さくなった.
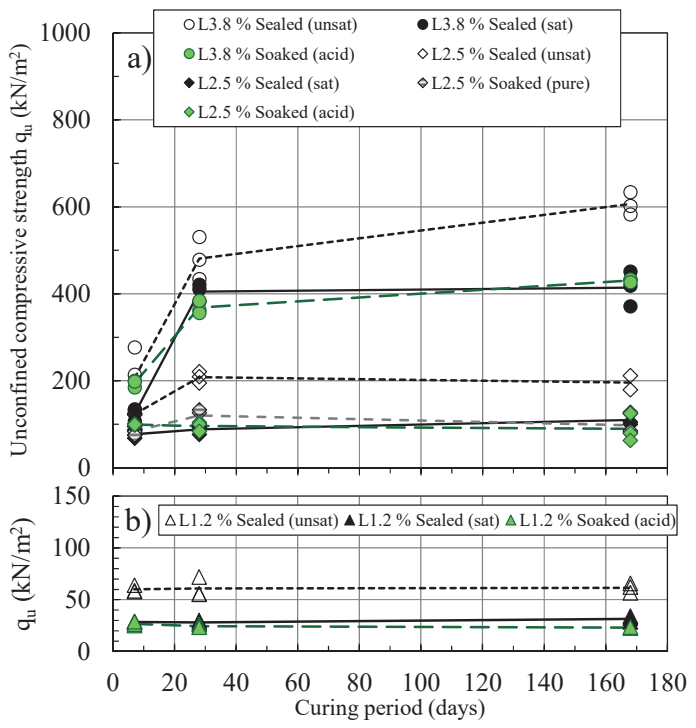

Fig. 4 Relationships between unconfined compressive strength of lime treated soils and curing period.
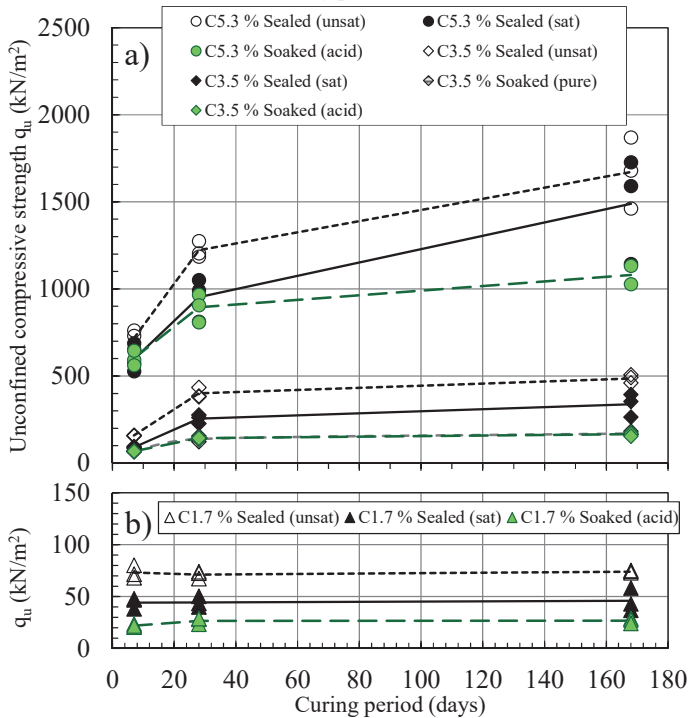

Fig. 5 Relationships between unconfined compressive strength of cement treated soils and curing period.
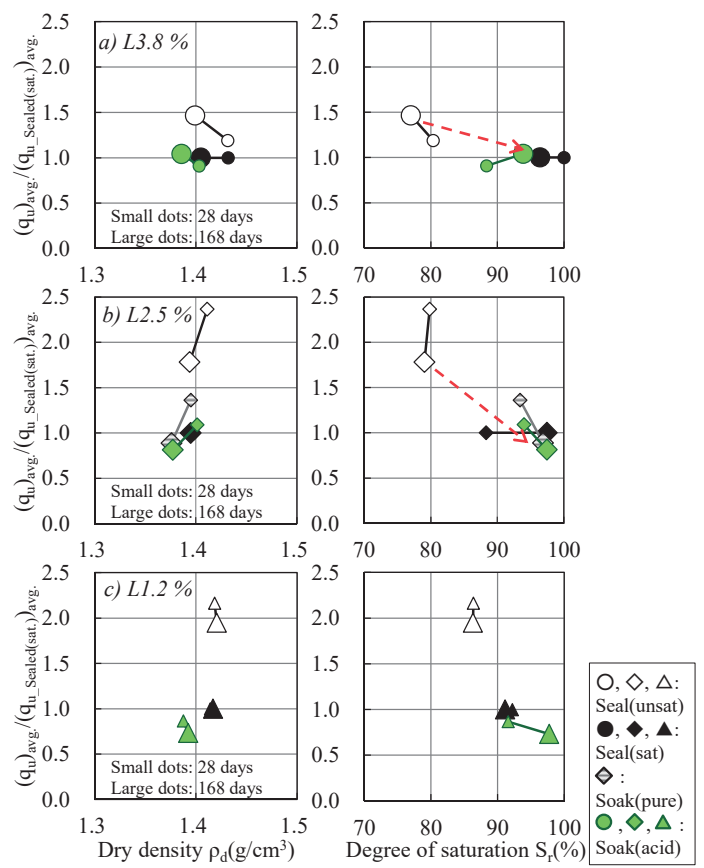

Fig. 6 Relationships between strength ratio, dry density and degree of saturation of lime treated soils.
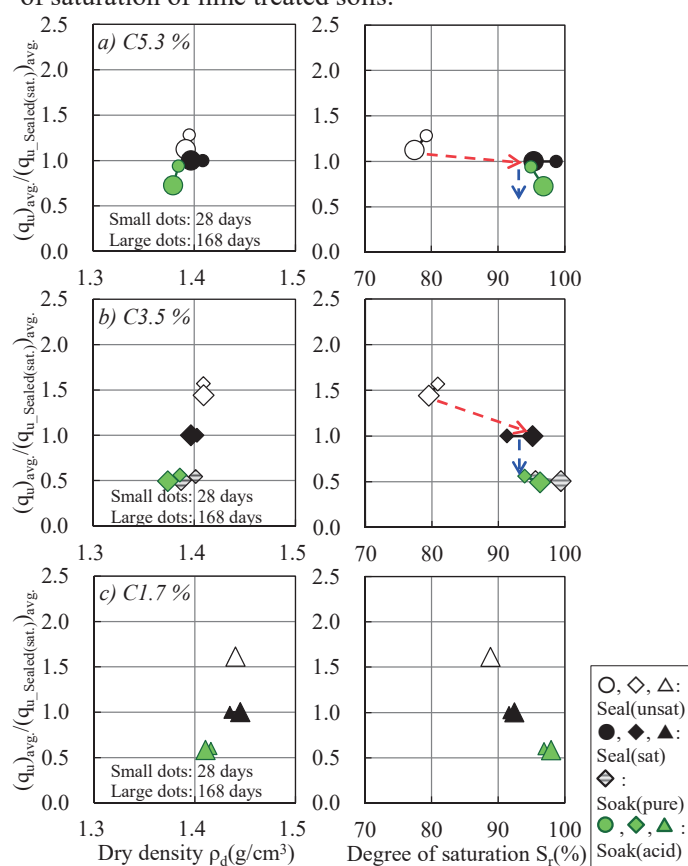

Fig. 7 Relationships between strength ratio, dry density and degree of saturation of cement treated soils.

石灰，セメント改良土の封縅（飽和）養生に対する封 縅 (不飽和), 水浸養生の $\mathrm{qu}$ 值の比 (強さ比) と乾燥密度, 飽和度との関係を Figs. 6，7 にそれぞれ示す。強さ比は， 各養生条件での $\mathrm{qu}_{\mathrm{u}}$ 值の平均を封緘（飽和）養生の $\mathrm{qu}_{\mathrm{u}}$ 值の 平均（(qu_封䋞 (飽和) $)$ 平均) で除した值である. Fig. 6 より, 石灰改良土の封縅（不飽和）養生の強さ比は L3.8\% で 1 より大きく, L2.5, $1.2 \%$ で 1.8 以上であった. 各養生条件 の供試体の乾燥密度に有意な差は見られなかった一方で, 封縅（不飽和）養生の供試体の飽和度（含水比）は封緘 （飽和）養生よりも低かった，材齢 28 日の L2.5\%にた いて多少のばらつきが見られるが，水浸養生の強さ比は 
概ね 1.0 程度であり，封緘（飽和）と水浸養生の供試体 の乾燥密度と飽和度は同程度であった。封緘（飽和）と 水浸養生では，供試体の飽和度の増加に伴うサクション の低下により $\mathrm{qu}_{\mathrm{u}}$ 值が低下したと考えられる。

Fig. 7 によると，セメント改良土の封縅（不飽和）養生 の強さ比は C5.3\% で 1 より大きく, C $3.5,1.7 \%$ では 1.5 〜 1.6 程度であった. 封緘（飽和）養生との強度の差は, 石灰改良土と同様に飽和度の違いによるものであると考 えられる.C3.5, $1.7 \%$ では 28 日から，C5.3\%において も 168 日から, 水浸養生の強さ比はいずれも 1 より小さ い值であった。封縅（飽和）と水浸養生の供試体の乾燥 密度，飽和度は概ね同じ範囲にあり，セメント改良土の 封緘（飽和）養生と水浸養生の $\mathrm{qu}_{\mathrm{u}}$ 值の違いは物理的性質 のみでは説明できなかった。

\section{$3 \cdot 2$ 改良土の一軸圧縮強さに及ぼす化学的性質の影響}

石灰，セメント改良土の材齢 280 日までの養生水の a) $\mathrm{pH}$ の経時変化，b) Ca イオンの累積溶脱量，c) $\mathrm{SO}_{4}$ イオン の累積溶脱量をそれぞれ Figs. 8 ，9 に示す. 初期材齢で約 11 12 だった石灰改良土養生水の交換時の $\mathrm{pH}$ は，168日 で約 9.5 11 まで低下した。 セメント改良土養生水の初期 材齢での $\mathrm{pH}$ は石灰改良土よりもやや低い約 10.5 11.5 で, 168 日で約 9 10.5 まで低下した。混合率の低い改良土の 養生水ほど $\mathrm{pH}$ の低下が初期から著しかった。

Fig. 8，9の Ca，SO4イオンの累積溶脱量は 1 供試体あ たりの両イオンの溶脱量に相当する. 図中に材齢 28,168 日における累積溶脱率を表示寸る。累積溶脱率は石灰, セメントの Table 2 の化学組成と混合率に基づいて $\mathrm{Ca}, \mathrm{S}$ 量の改良による増分を求め, $\mathrm{Ca}, \mathrm{SO}_{4}$ の累積溶脱量を除し て求めた值である。ただし，石灰改良土からの $\mathrm{SO}_{4}$ イオ ンの溶脱は美浦砂の成分に起因寸るものと考えられるた め, 溶脱率は計算しない. 石灰改良土の材齢 168 日の $\mathrm{Ca}$ 溶脱率は混合率によらず概ね $30 \%$ 弱であった。 セメン 卜改良土は混合率が小さいほど $\mathrm{Ca}, \mathrm{SO}_{4}$ の溶脱率が大き かった. $\mathrm{SO}_{4}$ の溶脱率は $\mathrm{Ca}$ の溶脱率よりも高く, 特に C1.7, $3.5 \%$ では初期材齢における溶脱の進行が顕著であった. 材齢 280 日までは養生水の水質による $\mathrm{pH}$ と Ca 溶脱量の 顕著な差は認められなかった。 $\mathrm{C} 3.5 \%$ の $\mathrm{SO}_{4}$ 溶脱量は模 擬酸性雨養生でわずかに大きかった.

セメント改良土の水浸養生による $\mathrm{pH}$ の低下, $\mathrm{Ca}$ イオ ンの溶脱と，これら化学的性質の変化に伴う改良土の劣 化（強度の低下） は多くの既往研究で報告されてきた. 例えば土田ら ${ }^{1)}$ は，海水環境下で供試体表面からエトリ ンガイトの消失を示唆する X 線回折分析（以下，XRD と いう）結果が得られたことを報告している．本研究の模 擬酸性雨と純水による養生環境下でも， $\mathrm{Ca}, \mathrm{SO}_{4}$ イオンが 溶脱して強度に寄与する水和物が消失，または生成阻害 されたことが一因となり，封縅（飽和）養生と比較して 水浸養生の $\mathrm{q}_{\mathrm{u}}$ 值が小さくなった可能性が考えられる.

養生水の分析結果からは石灰改良土においても $\mathrm{Ca}$ の溶 脱が認められたが，Figs. 4，6によると，Ca の溶脱は材
齢 168 日までは一軸圧縮強さに影響を与えていなかった。 水浸養生は，ポゾラン反応などによる強度増加が本格的 に進行する前の材齢 4 日から開始した．材齢 168 日まで は, 強度に寄与せず溶脱しやすい $\mathrm{Ca}$ 成分などが主に供試 体の外に排出される段階であった可能性が考えられる.

本研究においても改良土の粉末試料に XRD，示差熱重 量分析を適用したが，石灰，セメント改良土の化学的性 質の変化と一軸圧縮強さの関係を定量的に説明可能な分 析結果は現段階で認められていない. 分析試料の準備方 法の改善と分析条件の精査を行い, 引き続き検討する.
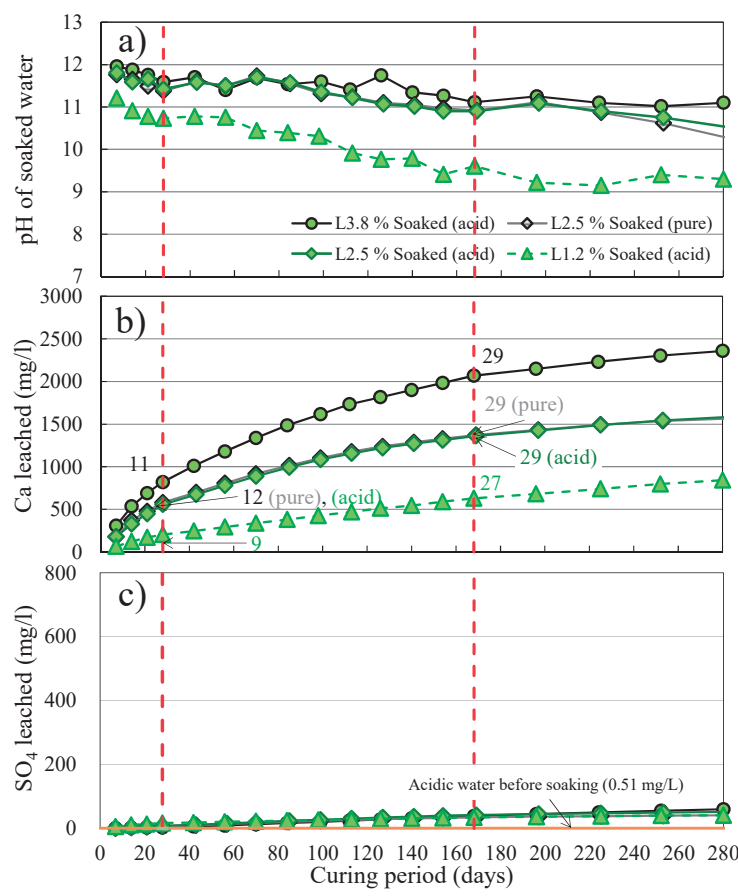

Fig. 8 Changes in a) $\mathrm{pH}$ value, accumulated amounts of b) $\mathrm{Ca}$ and c) $\mathrm{SO}_{4}$ in water after soaking of lime treated specimens.
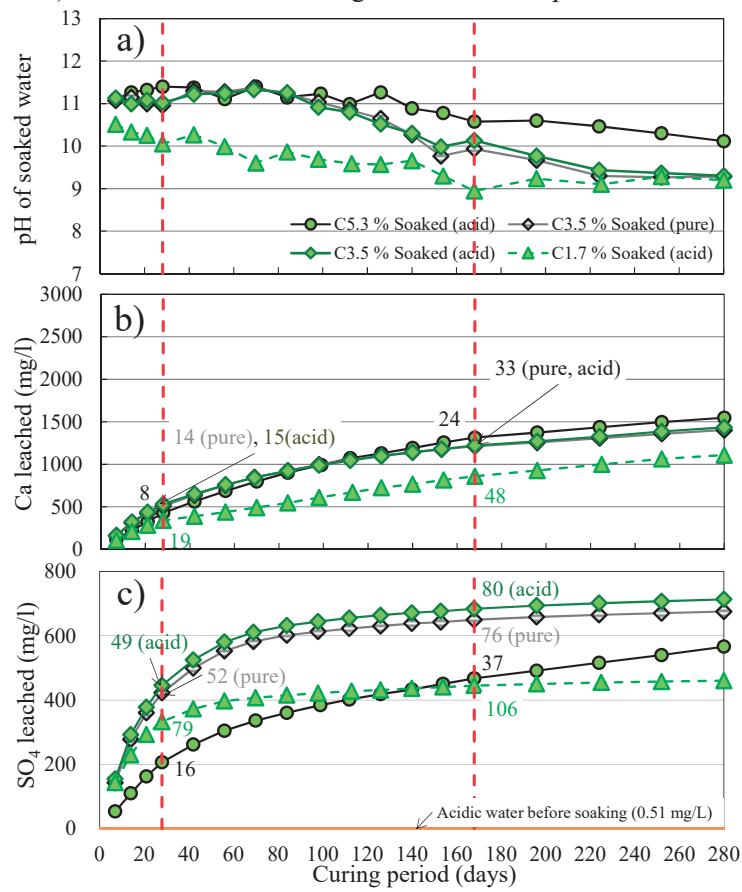

Fig. 9 Changes in a) $\mathrm{pH}$ value, accumulated amounts of $\mathrm{b}$ ) $\mathrm{Ca}$ and c) $\mathrm{SO}_{4}$ in water after soaking of cement treated specimens. 


\section{4 針貫入試験結果}

\section{$4 \cdot 1$ 供試体水平方向の局所的な針貫入抵抗比の評価}

基準ケース（L2.5，C3.5\%）の石灰，セメント改良土供 試体で実施した針貫入試験結果として，針の貫入深さと 貫入抵抗の関係を Figs. 10，11 にそれぞれ示す. 材齢ごと に封縅 (飽和)，水浸養生の代表的な計測結果を比較した。 石灰改良土 (L2.5\%) では材齢が大きくなっても各養生条 件の貫入抵抗の最大值に有意な変化は認められなかった。 また，各材齢において任意の深さでの貫入抵抗の大小関 係には明瞭な傾向がなく，封縅（飽和）養生が水浸養生 を下回る場合もあった。 セメント改良土（C3.5％）では いずれの養生条件においても針貫入抵抗の最大值が日数 の経過と共に大きくなった，材齢 28，168 日では，任意 の深さでの水浸供試体の貫入抵抗が封緘（飽和）供試体 の貫入抵抗よりも小さかった．特に 168 日では，水浸供 試体の深さ $5 \mathrm{~mm}$ 以下の貫入抵抗が極めて小さかった.

封縅（飽和）養生と水浸養生の貫入抵抗の違いを定量 的に評価する試夕の一つとして，供試体表面からの任意 の深さでの針貫入抵抗比を評価した ${ }^{4)}$. 深さ $\mathrm{D}=2,5,10,20$ $\mathrm{mm}$ における水浸供試体の 3 測線での貫入抵抗を，封緘

（飽和）供試体の同一深さにおける 3 測線の貫入抵抗の 平均值で除した值を，各深度の針貫入抵抗比 $\mathrm{R}_{\mathrm{P}}$ とした。 L2.5，C3.5\%の水浸（酸性雨）供試体で求めた RP と材齢 との関係を Figs. 12，13 にそれぞれ示す．L2.5\%では，最 も浅い $\mathrm{D}=2 \mathrm{~mm}$ での $\mathrm{R}_{\mathrm{P}}$ 值が材齢 168 日のみで 1.0 を明ら かに下回ったが, $5 \mathrm{~mm}$ 以上の深さでは $\mathrm{R}_{\mathrm{P}}$ 值が概ね 1.0 以 上であり，深度方向の応力比に明確な違いはなかった。

Needle penetration resistance $\mathrm{P}(\mathrm{N})$ $\begin{array}{llllllllllllllll}0 & 10 & 20 & 30 & 40 & 500 & 10 & 20 & 30 & 40 & 500 & 10 & 20 & 30 & 40 & 50\end{array}$

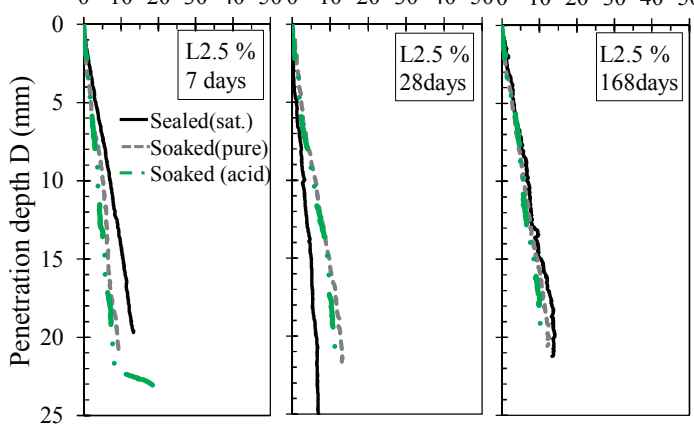

Fig. 10 Relationships between needle penetration resistance and depth of lime treated soils.

Needle penetration resistance $\mathrm{P}(\mathrm{N})$

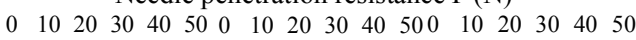

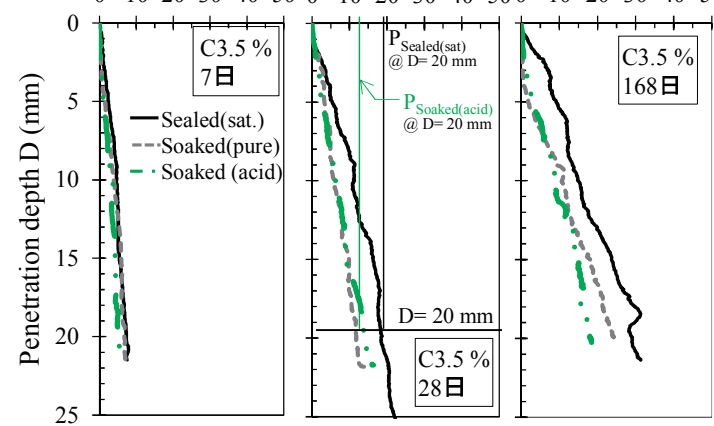

Fig. 11 Relationships between needle penetration resistance and depth of cement treated soils.

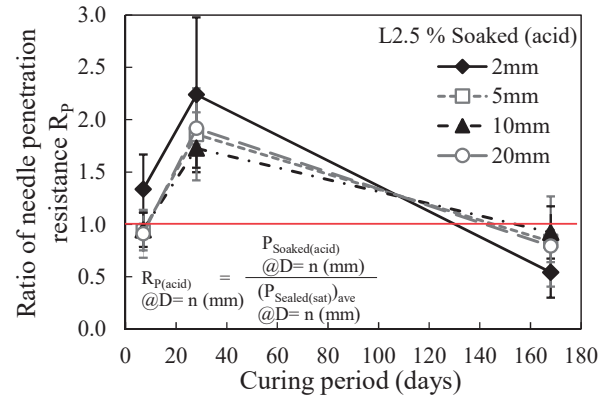

Fig. 12 Relationships between ratio of needle penetration resistance and curing period in lime treated soil.

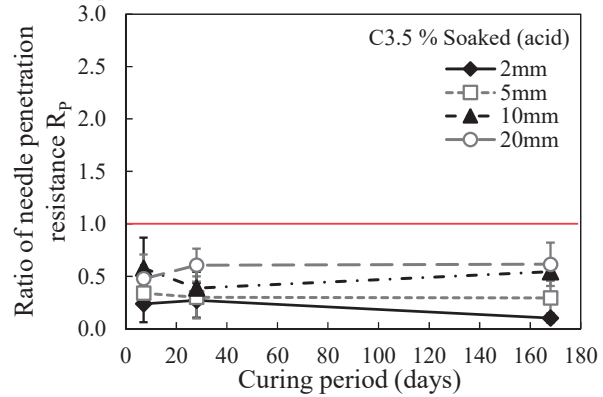

Fig. 13 Relationships between ratio of needle penetration resistance and curing period in cement treated soil.

一方，C3.5\%では材齢 7 日からすべての深さで $\mathrm{R}_{\mathrm{P}}$ 值が 1.0 よりも小さかった，特に材齢 168 日においては，貫入 深さが浅いほど RP值が小さくなっていた。

石灰，セメント改良土の RP 值の傾向は一軸圧縮強さの 傾向と概ね一致した。 寸なわち, 石灰改良土では水浸供 試体の任意の深さでの強度特性が封縅（飽和）供試体と 概ね同様で，一軸圧縮強さにも養生条件の差の影響が現 れなかった。 セメント改良土では水浸供試体の局所的な 強度が封縅（飽和）供試体の強度よりも小さく，その差 は供試体表面に近いほど顕著であった。その結果，一軸 圧縮強さは水浸供試体で最も小さくなったと考えられる.

\section{$4 \cdot 2$ 劣化深度, 局所的な針貫入抵抗比に及ぼす供試体} 横断面の化学的性質の変化の影響

EPMA による分析結果として，C3.5\%の材齢 168 日の 封縅（飽和）供試体（a），28 日の水浸（酸性雨）供試体 (b)，168 日の水浸（酸性雨）供試体（c）の横断面での Ca，S イオンの分布を Fig. 14 に示す. 封縅（飽和）と水 浸（酸性雨）の供試体の $\mathrm{Ca}$ 分布の差は明瞭であり，水浸 (酸性雨) 養生では供試体表面から中心に向かう $\mathrm{Ca}$ の溶 脱が示唆された. 定量值が小さいため分布の差は $\mathrm{Ca}$ ほど 明瞭でないが，封緘（飽和）供試体と比較すると材齢 168 日の水浸（酸性雨）供試体の $\mathrm{S}$ 量は断面全体で少なく, 中心部まで溶脱が進行していた可能性が示唆された。

$4 \cdot 1$ で試算したセメント改良土の RP 值と Fig. 14 の各 イオン分布との関係を調べる目的で，図中に示す白枠の 範囲 $\left(5\right.$ x $\left.50 \mathrm{~mm}^{2}\right)$ を 5 x $1 \mathrm{~mm}^{2}$ の区画に分割し，1 区画ご との $\mathrm{Ca}, \mathrm{S}$ 量の平均值の直径方向の変化を各イオン分布 の下に表示した。間隙に充填された樹脂に含まれる炭素 の分析結果を利用して, 白枠内に存在する間隙の位置と 大きさを推定し，各区画の $\mathrm{Ca}, \mathrm{S}$ 量の平均值への間隙の 


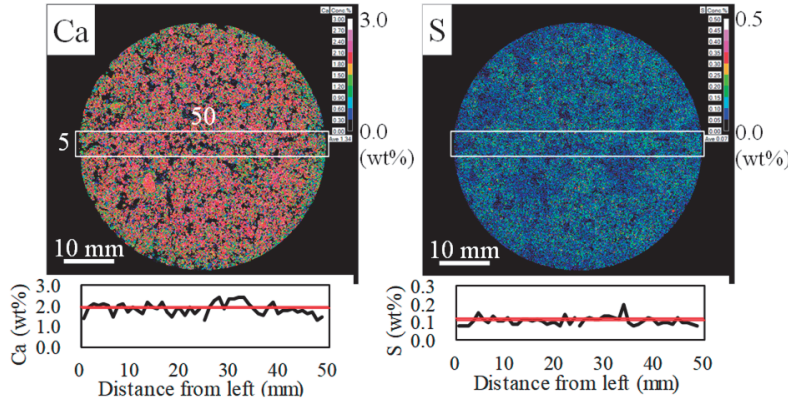

a) C3.5\% Sealed (sat.), 168 days

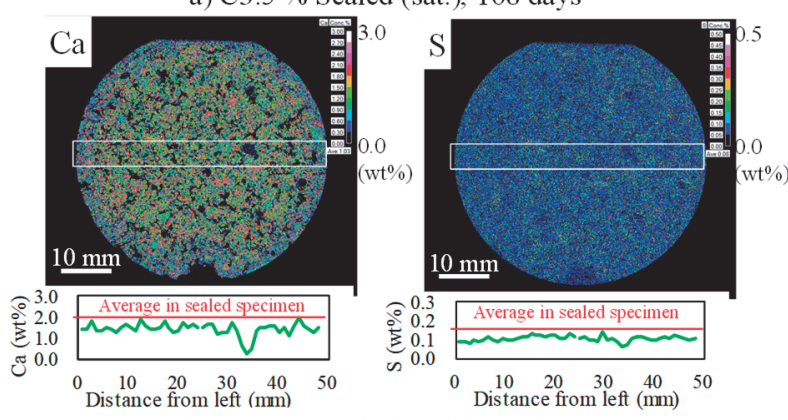

b) C3.5\% Soaked (acid), 28 days

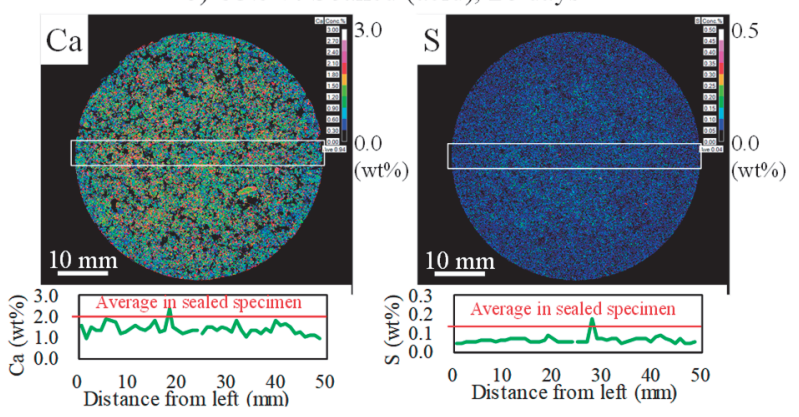

c) C3.5\% Soaked (acid), 168 days

Fig. 14 Distribution of $\mathrm{Ca}$ and $\mathrm{S}$ ions in cross section of cement treated specimens by EPMA.

影響を低減する補正を施した。封緘供試体の $\mathrm{Ca}$ 量, $\mathrm{S}$ 量 は直径方向に一定であると仮定し，50 区画の平均值を赤 の実線で併記した．数区画の例外を除くと，水浸供試体 の各区画の $\mathrm{Ca}, \mathrm{S}$ 量は封緘供試体の全区画の平均值より も小さかったが，供試体の表面付近と中心部で区画ごと の值に明確な違いは現れなかった。 RP 值によると，供試 体表面の数 $\mathrm{mm}$ の範囲で局所的な強度が小さいことが 確認されたが，これらの傾向と $\mathrm{Ca} ， \mathrm{~S}$ イオンの表面から の溶脱との関係を定量的に説明するのは現段階では難し いようであった。観察断面の研磨では水溶性のイオンが 流出しないようにコンクリートの基準（案）5りに準拠した 有機溶媒による研磨を行う他, 各区画に含まれる土粒子 の影響を平均值の計算で補正することを試みるなど， EPMA の分析精度の向上，評価手法の改良を行い，セメ ント改良土供試体の局所的な強度特性と局所的な化学的 性質との関係を明らかにすることが今後の課題である.

引き続き長期間の暴露実験を継続し, 定期的に力学特 性への物理，化学的性質の影響を検討する予定である. 本論文に示した実験，分析に加えて，改良土の保水性試 験を行い，飽和度とサクションの関係を明らかにするこ とで，物理的性質の影響を定量的に評価することを試み る. さらに, 長期材齢の粉末試料に XRD や示差熱重量分
析などを適用し, 石灰, セメント改良土の力学特性に寄 与する化学成分の定量を試みる.

\section{5 結言}

生石灰，セメント系固化材を低品質な砂質土に混合し て作製した改良土供試体を封緘，水浸養生し，力学特性 に及ぼす物理，化学的性質の影響を調べた。

石灰，セメント改良土のすべての混合率において，封 縅（不飽和）養生で最も高い $\mathrm{qu}_{\mathrm{u}}$ 值が得られた。石灰改良 土では, 水浸養生と封緘（飽和）養生の $\mathrm{qu}_{\mathrm{u}}$ 值, 針貫入試 験結果がほぼ等しく，材齢 168 日までの水浸養生による 封縅（不飽和）養生との強度の差は，飽和度の違いによ るものであることが分かった. 水浸養生供試体では $\mathrm{pH}$ の 低下や Ca の溶脱が確認されたが，材齢 168 日まではこれ らの化学的性質の変化は水浸養生供試体の力学特性に影 響を与えていなかった。

セメント改良土では, 日数の経過に伴って水浸養生の $\mathrm{q}_{\mathrm{u}}$ 值が封緘（飽和）養生の強度を下回った. 針貫入試験 においても，水浸養生供試体の表面付近の局所的な強度 が封縅（飽和）養生よりも小さかった。これらの強度の 差は, $\mathrm{Ca}, \mathrm{SO}_{4}$ イオンが溶脱して強度に寄与寸る水和物が 消失，または生成阻害されたことによると考えられる.

今後も長期間の暴露実験を継続し, 改良土の力学特性 に及ぼす物理，化学的性質の影響について検討する.

本論文は, 土木研究所と産学計 12 者による共同研究「建設 発生土等の長期的な品質管理向上技術に関する共同研究」の成 果の一部をとりまとめたものである. 論文の作成にあたり, 共 同研究参加者から貴重な助言をいただいた.ここに記して感謝 の意を表す.

\section{参 考 文 献}

1) T. Tsuchida, J. Kasai, J. Mizukami, Y. Yokoyama and K. Tsuchida, "Effect of curing condition on mechanical properties of light-weight soils", Technical Note of the Port and Harbour Research Instisute, Ministry of Transport, Japan, No. 834 (1996).

2) H. Hara, D. Suetsugu and H. Matsuda, "Progress speed of deterioration of cement and lime treated soil immersed in seawater", 9th International Symposium on Lowland Technology, pp. 169-173 (2014).

3) T. Ota, Y. Miyashita, T. Hashimoto and H. Nakamura, "Experimental study on compaction of lime and cement treated soils", Proceedings of the 13th National Symposium on Ground Improvement, pp. 277-284 (2018).

4) P. Ngoc, B. Turner, J. Huang and R. Kelly, "Experimental study on the durability of soil-cement columns in coastal areas", 19th Southeast Asian Geotechnical Conference \& 2nd AGSSEA conference, (2016).

5) Sub-Committee on New Standards, Committee on Concrete, JSCE Standards "Area Analysis Method of Elements Distrubution in Concrete by Using EPMA", Journal of Japan Society of Civil Engineers, E, Vol. 62, No.1, pp. 246-259 (2006). 